\section{Social networks of men who have sex with men: a study of recruitment chains using Respondent Driven Sampling in Salvador, Bahia State, Brazil}

\author{
Redes sociais de homens que fazem sexo com \\ homens: estudo das cadeias de recrutamento \\ com Respondent Driven Sampling em \\ Salvador, Bahia, Brasil
}

Las redes sociales de hombres que mantienen sexo con hombres: estudio de muestreo en cadena con Respondent Driven Sampling en Salvador, Bahía, Brasil

\author{
1 Instituto de Saúde Coletiva, \\ Universidade Federal da \\ Bahia, Salvador, Brasil. \\ 2 Instituto de Matemática, \\ Universidade Federal da \\ Bahia, Salvador, Brasil. \\ 3 Instituto de Física, \\ Universidade Federal da \\ Bahia, Salvador, Brasil. \\ ${ }^{4}$ Faculdade de Medicina, \\ Universidade Federal da \\ Ceará, Fortaleza, Brasil. \\ Correspondence \\ S. M. S. Brignol \\ Instituto de Saúde Coletiva, \\ Universidade Federal da \\ Bahia. \\ Rua Padre Feijó s/n, Campus \\ Universitário do Canela, \\ Salvador, BA 40110-040, \\ Brasil. \\ sandrabrignol@gmail.com
}

\begin{abstract}
Social and sexual contact networks between men who have sex with men (MSM) play an important role in understanding the transmission of HIV and other sexually transmitted infections (STIs). In Salvador (Bahia State, Brazil), one of the cities in the survey Behavior, Attitudes, Practices, and Prevalence of HIV and Syphilis among Men Who Have Sex with Men in 10 Brazilian Cities, data were collected in 2008/2009 from a sample of 383 MSM using Respondent Driven Sampling (RDS). Network analysis was used to study friendship networks and sexual partner networks. The study also focused on the association between the number of links (degree) and the number of sexual partners, in addition to socio-demographic characteristics. The networks' structure potentially facilitates HIV transmission. However, the same networks can also be used to spread messages on STI/HIV prevention, since the proximity and similarity of MSM in these networks can encourage behavior change and positive attitudes towards prevention.
\end{abstract}

Male Homosexuality; Sexual Behavior; HIV; Social Networking
Sandra Mara Silva Brignol 1

Inês Dourado 1

Leila Denise Amorim 2

José Garcia Vivas Miranda 3

Lígia R. F. S. Kerr 4

\section{Resumo}

As redes sociais e de contato sexual entre homens que fazem sexo com homens (HSH) têm um papel importante na compreensão da ocorrência de doenças sexualmente transmissiveis (DST) e HIV, devido ao potencial de circulação de agentes infecciosos nestas estruturas. Dados da Cidade de Salvador, Bahia, Brasil, que integraram a pesquisa Comportamento, Atitudes, Práticas e Prevalência de HIV e Sífilis entre Homens que Fazem Sexo com Homens em 10 Cidades Brasileiras foram coletados em 2009 numa amostra de 383 HSH por meio da técnica Respondent Driven Sampling (RDS). Análise de redes sociais foi utilizada para investigar as redes de amigos e parceiros sexuais. Também foi avaliada a relação entre o número de conexões (grau) o número de parceiros sexuais e as características sociodemográficas. As redes apresentaram estruturas que facilitam a transmissão do HIV. Porém, podem ser exploradas para a disseminação de informações sobre a prevenção do HIV e DST, visto que a proximidade e similaridade dos HSH nessas redes podem influenciar comportamentos e atitudes positivas para a prevenção.

Homossexualidade Masculina; Redes Sociais; HIV; Comportamento Sexual 
The organization of the homosexual/gay community and identity in large Brazilian cities took place within the historical context of the social, economic, and political changes that shaped the country's demographic transition beginning in the 1950s 1,2. However, homosexuals migrated to Brazilian cities during this period for reasons other than the economic motivation that characterized migration by the general population. Such factors included placing a distance between themselves and family surveillance and social repression, as well as the search for anonymity, homosexual/gay sociability, and sexual freedom $3,4,5,6$.

The "political opening" of the 1970s and 1980s 3,4 included an increasing struggle for sexual rights and greater visibility for the homosexual world and influenced the migration of gays to Brazil's large cities, especially São Paulo and Rio de Janeiro, with growth in the "ghettos" of homosexual/gay circulation and sociability 3,4,5. This movement led to greater visibility for gay identity and culture $3,4,5,6$. In addition to the country's overall political and social gains in recent decades, public policies for human rights were created and consolidated 7,8. Meanwhile, this same visibility brought other consequences such as the stigma, discrimination, and violence that mark the daily lives of many gay Brazilians 9,10 , even in the large cities, in a society that has proven historically intolerant to homosexuality 10,11 .

The difficulties in living in large Brazilian cities, with poor quality of services in transportation, public security, education, and health, affects all urban Brazilians 1,2, including men who have sex with men (MSM), whether openly homosexual/ gay men or men with a heterosexual social identity and homoerotic practices. In addition, many areas of the large cities lack major public services, thus creating an underlying social vulnerability in the rapid urbanization process that Brazil has experienced since the mid-20th century 1,2 .

Urban health is a branch of public health that studies risk factors in cities and the effects on health and social relations 1,2 . In this context, the organization of social networks in communities as a form of local support and empowerment highlights the importance of such structures in the context of the urban population's health. A major challenge for public health is thus to understand the role and influence of these networks and their relationship to health issues ${ }^{2}$.

As in other contexts, in homosexual/gay sociability, social networks serve as a form of support for individuals, with different types of "networks" (friendship, community based organization, and cultural and sexual networks) 3,4,5,6,12 .
These networks provide not only the possibility for socialization and homoerotic activities but also mobility and social support 2,3,4,5,12. According to some researchers, these networks branch out, overlap, and intersect, leading to interaction between individuals from different social classes and social positions, and areas of the city, via intense mobility: from the city center to the periphery, across metropolitan areas, from the countryside to the capital cities, from small to large cities, and between geographic regions $3,4,5,12$.

Social scientists have studied the organization of relations in social networks since the 1930s 13. In physics, network theory was systematized and presented in the 1950s 14 and has advanced over the years with the identification of different patterns in these structures 15. Researchers developed a series of theories that included random networks 14 , small-world networks 16, and scale-free networks 17, identified in the late 1990s, that help explain the networks' various characteristics and functioning, with their potentialities and vulnerabilities 15,18.

It is now widely accepted that humans are connected through a large network of social relationships 13,15,16,17. People connect by strong or close ties with friends and relatives, as well by weaker ties (indirectly) with friends of friends, or with acquaintances, distant relatives, former coworkers, and neighbors 15,16. Considering this configuration of relationships, human beings are separated from each other by an average of six degrees, that is, six persons, but these influences occur most intensely within three degrees (the socalled "three degrees of influence" rule) 15 . Recent studies have analyzed sexual contact networks of MSM in the context of HIV and other sexually transmitted infections 19 . The importance of these networks is due mainly to the circulation of infectious agents, with the potential for rapid transmission in large sexual partner networks in the presence of risky sexual practices such as unprotected sex, especially between serodiscordant individuals 19 .

As in other populations, MSM are connected through different social networks (friends, sexual partners, and individuals that frequent public and private venues for gay sociability) 3,4,5,6,12. But they also connect with men that identify as heterosexuals but have homoerotic and sexual practices with other men $3,4,5,6,12$. It is thus difficult to organize a mapping or census of MSM, or a random sample, due to issues of stigma, discrimination, criminalization of sexual practices, and the diversity of social venues.

This study focus on a sample of MSM in Brazil's third largest city 20 , with the following objec- 
tives: (1) to identify the network structure among the participants' closest friends and sexual partners and (2) to analyze the associations between the number of links between study participants (degree) and the number of sexual partners, and with key socio-demographic characteristics. Salvador, the capital of Bahia State, like other large Brazilian cities, suffers from major social inequalities, ranking 383rd in the country's Municipal Human Development Index (MHDI) 21, impacting the population's health 22 members of vulnerable groups 1,2 .

\section{Methodology}

\section{Study design}

Salvador was one of the sites selected for the behavioral and biological survey entitled Behavior, Attitudes, Practices, and Prevalence of HIV and Syphilis among Men Who Have Sex with Men in 10 Brazilian Cities 23, conducted from October 2008 to October 2009. The overall study selected a total of 3,859 MSM from the 10 cities 23 , using a recruiting technique known as Respondent Driven Sampling (RDS) 24, a variant of the "snowball" network sampling technique 25 in which selected participants (seeds) begin the formation of recruitment chains. RDS selects a sample from the recruiters' network of relationships, and the method is recommended for studying hard-toreach groups such as drug users, sex workers, and MSM 26. RDS places some restrictions on participant selection due to ethical or operational reasons or to meet inclusion or exclusion criteria. In the current study, the restrictions were: each recruiter indicated up to three other MSM from his network of personal relationships to participate in the study and who were at least 18 years old, who reported having had sex with at least one other man in the previous year, and who had a wide network of personal relationships with other MSM 23,27.

\section{Recruitment}

The study started with focus groups of MSM from different social classes, ages, and sexual identities, to identify the study population's preferences as to study site and type of incentives to participate, besides selecting some MSM with broad networks of personal relationships and who agreed to be "seeds", that is, to begin the recruitment of other MSM. The "seeds" and other participants received three numbered invitations (coupons) with expiration dates to distribute to MSM in their network of personal relationships (friends and sexual partners). In Salvador, 394 MSM were recruited, of whom 383 met the inclusion criteria and comprised the final study sample 27 (Figure 1).

\section{Study variables}

The variables used to describe the RDS recruitment process were: (1) size of the overall network of participants' personal relationships, identified with the following question: How many men do you know and that know you, and that you think have sex with other men, and that live in Salvador?; (2) Size of the network of MSM 18 years or older, identified with the question: Of these men that you mentioned, how many are 18 years or older?; (3) Size of the network of closest MSM, identified with the question: How many of these men 18 years or older have you met with or spoken to personally or by telephone or internet in the past two months?; (4) Size of friendship network, identified with the question, Of these MSM, who are 18 years or older, and that you met with or spoke to in the past two months, how many would you invite to participate in this study?, an this variable was used to estimate degree (number of links in each participant's network, or self-reported degree); (5) Size of the sexual partner network, identified with the question: Of these men that you mentioned having met with or spoken to in the past two months and that you would invite to participate in the study, with how many have you had sex, that is, oral sex (penis to mouth) or anal sex (penis into anus)?, and this variable was used to estimate the degree of MSM that had sexual partners within the network of closest friends (self-reported sexual degree); and (6) identification of links among participants in the network of personal relationships, identified with the question: of these men that you said you met with or spoke to in the past two months and that you would invite to participate in the study, how many do you think know each other?, and this variable was used as the number of links or edges (self-reported edges) in the friendship networks and sexual partner networks 27 .

The variables on sexual risk practices for HIV infection were constructed from the following questions: (1) With how many partners have you had sex in the past 6 months (how many sexual partners have you had, that is, persons with whom you had oral, vaginal, or anal sex)?; (2) Of these, how many were men?; (3) With how many casual partners have you had sex in the past 6 months?; (4) How many of these were men?; 5) With how many steady partners have you had sex in the past 6 months?; (6) How many of these were men?; (7) With how many commer- 


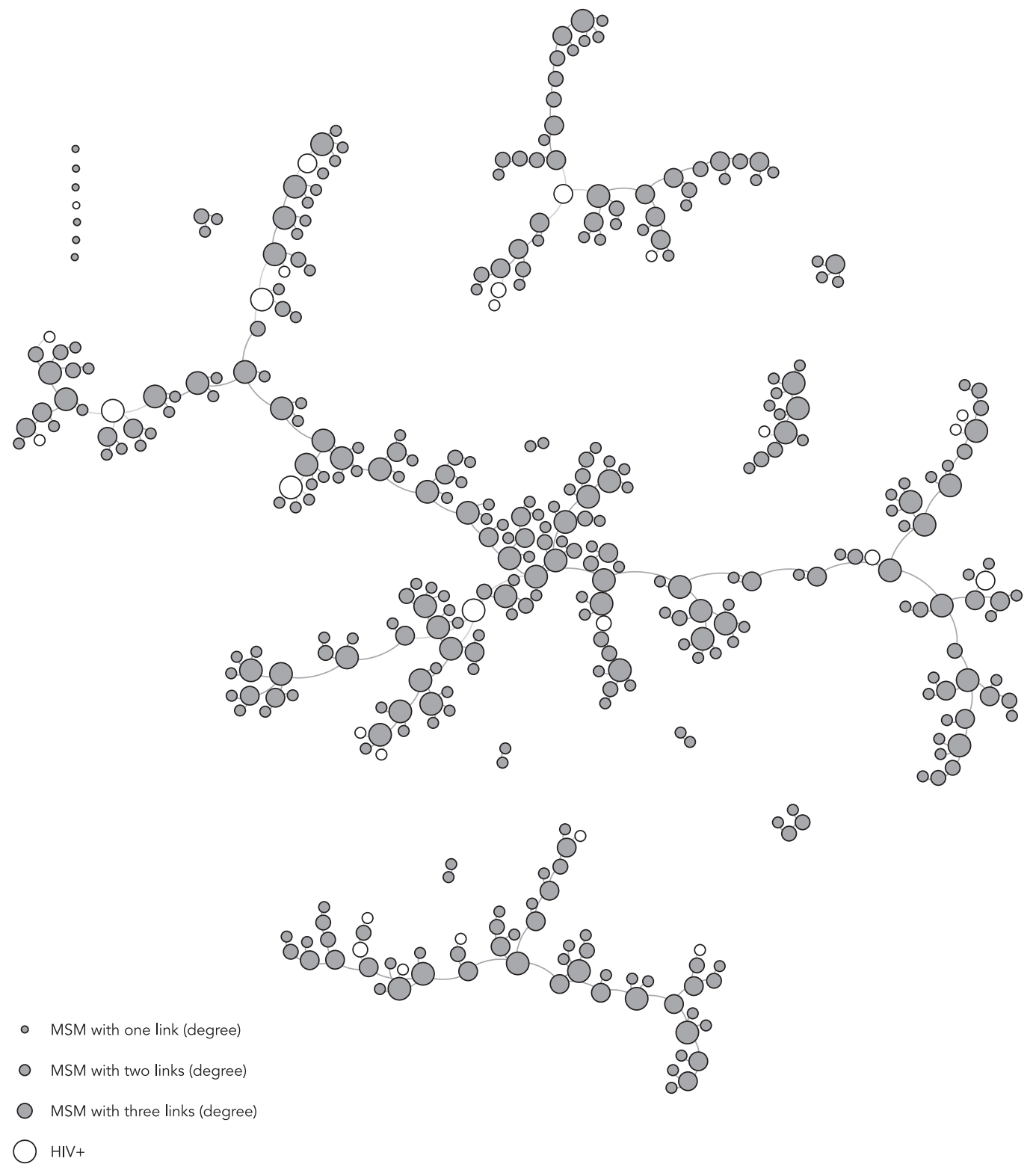

MSM: men who have sex with men.

cial sex partners have you had sex in the past six months?; (8) Of these, how many were men? The selected social and demographic variables were: monthly family income, years of education, age, sexual identity (MSM - heterosexuals, bisexuals, homosexuals/gays), and local gay venues used for meeting sexual partners 27. Presence of HIV infection was tested with Rapid Check HIV-1\&2 and Bio-Manguinhos HIV-1\&2 23,27.

\section{Data analysis}

Continuous variables were analyzed by their means, medians, quartiles, or percentiles, and 
standard deviations, as well as histograms and box-plot analyses. Correlations between numerical variables with reported degree (links with friends and sexual partners), number of male sexual partners, total sexual partners (men, women, and transvestites), age, years of education, and family income were tested with the Spearman correlation coefficient 28,29 . Data normality was tested with the Shapiro-Wilk test 28,29. All the statistical tests set significance at $5 \%$ and were performed with Stata version 10.0 (StataCorp LP, College Station, USA). Analyses of friendship networks and sexual partner networks used the participants' reports as an estimate of degree for MSM and their edges, as described previously. These data were used to calculated the participants' mean degree and the global clustering coefficient 30,31. This coefficient provides an approximation of the probability that any two neighboring vertices in a common node are linked to each other. The greater the " $C$ ", the more clustered the network, that is, the links tend to form a large single block containing many connected individuals. This indicates that a large number of neighboring individuals in the network without direct connections are also connected, but via other relationships 30 .

To classify the study's networks, we used the technique indicated in the literature to simulate a random network using the parameters reported by participants for friendship networks and sexual partner networks, in addition to calculating the minimum mean path, or closeness and betweenness centrality correlations 30,31 . Further more, we analyzed the relationship between reported degree $(\mathrm{X})$ and respective probabilities, calculated as the approximation of the relative frequency $(\mathrm{P}(\mathrm{X}=\mathrm{k})=$ number of occurrence of vertices with degree $\mathrm{k} /$ total number of vertices in the network 29 .

To identify the distribution of the degrees and verify whether this distribution was analogous to a power law, i.e., whether $\mathrm{P}(\mathrm{X})=\operatorname{constant}(\mathrm{X})^{-\lambda}$, where $X$ is the observed degree of unity in the network 32 , the following items were evaluated: (1) the size of coefficient $\lambda$ in power law $P(X)=$ constant $(\mathrm{X})^{-\lambda}$, where $\lambda$ should be greater than two; (2) the relationship (whether linear or not) between the logarithm of the degree and the logarithm of the degree's probability (graph $\log P(X) \times \log (X)$ ), which removes the scale effect from the observed degree; (3) the degree's order of magnitude (greater than 1,000 units); and (4) the similarity between the distribution of $\mathrm{P}(\mathrm{X})=\mathrm{C}(\mathrm{X})^{-\lambda}$ and the distribution of the reported degrees (X) 32,33 . If all the items are met, distribution of the degrees is defined as a power law distribution, otherwise it is classified as a "heavy tail" distribution 33 .
We used the Kolmogorov-Smirnov test on a sample to examine the agreement between the distributions of the observed probabilities and power law. The Kolmogorov-Smirnov test verifies the adherence between the distribution of a set of data from the sample and a specified distribution 28 . We opted to remove the extreme number of sexual partners reported by one participant (3,650 MSM) from the set of reported degrees, given that it was highly discrepant from typical values and those found in the literature, and it was scarcely plausible that a person could have a network of more than 500 close friends 15,34,35,36.

The following programs were used in the analyses, simulations, and presentation of networks: Pajek 2.04 and 3.09 (http://pajek.imfm. si) and Gephi 0.8.2 beta (Graph Visualization and Manipulation software: http://www.gephi. com.br) - graphic formatting and calculation of the coefficient for friendship networks. The research protocol was conducted according to the ethical criteria of the Declaration of Helsinki and in accordance with the requirements of $R u l$ ing $n$. 196/96 of the Brazilian National Health Council. The research project was approved by the National Commission on Research Ethics of the Ministry of Health (CONEP) (protocol $\mathrm{n}$. 14,494) and the Committee on Research Ethics of the Bahia State Health Secretariat (protocol n. 241/2008).

\section{Results}

For the MSM in this sample, mean education was 11 years, mean age 25 years, and mean monthly family income BRL 1,733 (Table 1). Forty-nine percent of the participants identified themselves as homosexuals or gays and listed the following venues where they had gone to seek sexual partners in the previous 30 days: bars (12\%), nightclubs (14\%), friends' homes (12\%), Internet (12\%), parties (8\%), saunas $(5 \%)$, cinemas $(4 \%)$ and "cruising" bathrooms (2\%).

\section{Recruitment}

The participants' recruitment chains had 18 seeds that recruited 394 MSM, but of these, 11 MSM failed to meet the inclusion criteria and were excluded from the analyses. Four seeds were the most successful in recruiting, with $12,48,58$, and 235 participants, respectively, with the formation of the respective recruitment chains (Figure 1).

Participants reported knowing an average of 133 other MSM that also lived in Salvador, but the distribution proved highly asymmetrical, with a median of 30 MSM. Meanwhile, for the number 
Descriptive analysis of study participants' characteristics.

\begin{tabular}{|c|c|c|c|c|c|}
\hline RDS recruitment network & $\mathrm{n}$ & Mean & Median & Minimum & Maximum \\
\hline \multicolumn{6}{|l|}{ Demographic factors } \\
\hline Years of schooling & 382 & 11.4 & 11 & 1 & 22 \\
\hline Monthly family income (BRL) & 271 & 1,733 & 1,000 & 0 & 60,000 \\
\hline Age & 382 & 25.3 & 24 & 18 & 53 \\
\hline \multicolumn{6}{|l|}{ Recruitment } \\
\hline $\begin{array}{l}\text { How many men do you know and that know you, and that you think have sex } \\
\text { with other men, and live in Salvador? }\end{array}$ & 383 & 133 & 30 & 1 & 5,000 \\
\hline Of these men, how many are 18 or older? & 381 & 98.5 & 25 & 1 & 3,700 \\
\hline $\begin{array}{l}\text { How many of these men } 18 \text { or older did you meet with or speak to personally or } \\
\text { by telephone or internet in the last two months? }\end{array}$ & 379 & 38.1 & 10 & 1 & 3,650 \\
\hline $\begin{array}{l}\text { Of these men who have sex with men, that are } 18 \text { or older and that you met or } \\
\text { spoke with in the last two months, how many would you invite to participate in } \\
\text { this study? }\end{array}$ & 374 & 27.8 & 8 & 1 & 3,650 \\
\hline $\begin{array}{l}\text { Of these men that you met with or spoke to in the last two months and would } \\
\text { invite to participate in the study, with how many have you had sex? }\end{array}$ & 374 & 5.3 & 1 & 0 & 200 \\
\hline $\begin{array}{l}\text { Of these men that you met or spoke with in the last two months and that you } \\
\text { would invite to participate in the study, how many do you think know each other? }\end{array}$ & 369 & 11.9 & 5 & 0 & 200 \\
\hline $\begin{array}{l}\text { In the last two months, how often have you seen the person that gave you the } \\
\text { invitation for you to participate in the study? }\end{array}$ & 380 & 26.9 & 20 & 0 & 100 \\
\hline \multicolumn{6}{|l|}{ Sexual behavior (during the six months prior to the interview) } \\
\hline How many sexual partners have you had? & 362 * & 8.2 & 3 & 1 & 451 \\
\hline How many of these partners were men? & 342 * & 7.5 & 3 & 1 & 450 \\
\hline With how many steady partners have you had sex? & 241 & 1.3 & 1 & 1 & 5 \\
\hline How many of these steady partners were men? & 197 & 1.2 & 1 & 1 & 5 \\
\hline With how many casual partners have you had sex? & 284 & 6.2 & 2 & 1 & 150 \\
\hline How many of these casual partners were men? & 253 & 6.0 & 1 & 1 & 150 \\
\hline With how many commercial partners have you had sex? & 68 & 13.1 & 2 & 1 & 451 \\
\hline How many of these commercial partners were men? & 62 & 12.9 & 2 & 1 & 450 \\
\hline
\end{tabular}

* Total participants with some type of sexual partner in the previous six months (steady, casual, or commercial). The number of other types of partners is included in this group.

of closest MSM, i.e., whom they had contacted in the two months prior to the interview, the mean number was 38 MSM, also with an asymmetrical distribution, with a median of 10 MSM. By further limiting the closest MSM to those whom the participants would invite to participate in the study, the mean number dropped to $18 \mathrm{MSM}$, with a median of eight MSM (Table 1).

Among the MSM in the recruiters' network of personal relationships, a mean of 12 MSM were linked to each other, and $50 \%$ of the individuals in the network knew up to five other MSM within the network's structure. In addition, the participants reported having sex with a mean of five MSM in this structure, and $50 \%$ of the interviewees reported having sex with at least one MSM in their network of personal relationships (Table 1).
In the six months prior to participation in the study, the mean number of sexual partners was eight (men, women, and transvestites). Considering only male partners, the mean number was 7.5. For steady partners (men, women, and transvestites), the mean was one partner, while for casual sexual partners (men, women, and transvestites) the mean was six, a similar figure to that estimated for male casual partners during the same period. Mean age at sexual initiation was 14.7 years (Table 1 ).

\section{Correlations}

Correlation coefficients were statistically significant between the magnitude of links between participants (reported degree) in the friendship network and the following covariates: total number of 
sexual partners (men, women, and transvestites) $(0.20$; $p=0.0002)$; number of male sexual partners $(0.23 ; \mathrm{p}=0.0000)$; total casual partners (men, women, and transvestites) $(0.23 ; \mathrm{p}=0.0001)$; and number of male casual partners $(0.20 ; \mathrm{p}=0.0017)$. The correlation coefficients between reported degree in the sexual partner network and the following covariates were statistically significant: total sexual partners (men, women, and transvestites) $(0.33 ; \mathrm{p}=0.0000)$; male sexual partners $(0.36 ; \mathrm{p}=$ $0.0000)$; steady male partners $(0.18 ; \mathrm{p}=0.0143)$; total casual partners (men, women, and transvestites) $(0.28 ; \mathrm{p}=0.0000)$; and casual male sexual partners $(0.26 ; \mathrm{p}=0.0000)$.

The correlation between reported degree in the friendship network and socio-demographic variables showed statistical significance for: participant's age ( $0.18 ; \mathrm{p}=0.0008)$, family income $(0.22 ; p=0.0004)$; and years of education $(0.33$; $\mathrm{p}=0.0000$ ). For sexual partner network, the factors were the same as for friendship network: age $(0.12 ; \mathrm{p}=0.0173)$, family income $(0.13 ; \mathrm{p}=$ $0.0361)$; and years of education $(0.20 ; \mathrm{p}=0.0001)$.

\section{Topology of networks}

We analyzed friendship networks considering the MSM that participants would invite to participate in the study and found a global clustering coefficient (C) of 0.09 , as compared to 0.07 for the simulated small-world network and 0.02 for the simulated random network. The ShapiroWilk statistical test for normality in the distribution of the reported degree of the networks showed that these degrees did not follow a normal distribution. The correlation between reported degrees and their respective probabilities in the friendship network proved statistically significant $(-0.39$ and $p=0.0000)$. The mathematical function that describes this relationship is $\mathrm{P}(\mathrm{X})=$ $0.15 \mathrm{X}^{-(0.42)}$, where $\mathrm{P}(\mathrm{X})$ is the probability that a vertex in the network (MSM) with degree $\mathrm{X}$ will occur in the analyzed network. After removing the scale effect, the relationship remained significant (Figure 2a). However, the KolmogorovSmirnov adherence test showed that the abovementioned distribution of observed probabilities in the sample (approximated by the relative frequencies) and the probabilities described in the above-mentioned relationship are different, thus not confirming that the distribution of the reported degree follows a power law distribution for friendship network.

The sexual partner network, consisting only of the participants' sexual partners, showed a C of 1.0. The simulated small-world network showed $\mathrm{C}=0.07$ and the simulated random network $\mathrm{C}$ 0.01 (Table 2). Analysis of the correlation between reported degrees and their respective probabilities in the sexual partner network showed statistical significance $(-0.96 ; p=0.0000)$. Analysis of the distribution of the reported degree failed to confirm normal distribution. The equation that describes the relationship between reported degree and its probabilities is $\mathrm{P}(\mathrm{X})=0.15 \mathrm{X}^{-(0.79)}$, and even after removing the scale effect, the relationship remained significant (Figure 2b). The Kolmogorov-Smirnov test showed evidence that the distribution of the observed probability and the probability described by the relationship $P(X)$ are different, confirming that such distribution of degrees does not follow a power law.

\section{Discussion}

In the recruitment chains in Salvador (Figure 1), the mean number of MSM with whom the participants reported links in their personal network of relationships proved high (133 MSM), when compared to both the mean number in all 10 cities in the multicenter study (85 MSM) and the mean number of links reported by other studies on friendship networks and sexual behavior $34,35,36,37$. This number is close to the human capacity to relate to other persons in a large social network, or approximately 150 persons 15 . Thus, the findings suggest that the participants belong to a large network of personal relationships among MSM.

Studies on sexually transmitted infections have shown that in some networks, a high number of sexual partners is related to large size of the social network of MSM 19,37, which our study corroborated for both casual and steady partners. Although some correlations were moderate, they were statistically significant, indicating that the more the links among MSM, the more the sexual partners. In addition, participants reported having sex with an average of five of their contacts in their personal network of relationships, representing approximately $4 \%$ of the total number of men in this network and $18 \%$ if one considers the mean number of closest acquaintances in the network of MSM, i.e., with whom they had contact in the two months prior to the interview. Given this reality, risky sexual practices for sexually transmitted infections among serodiscordant individuals (positive and negative for STIs) in the same network of personal relationships 19,38,39 should be an important focus on prevention strategies.

Infectious agents can circulate quickly in these sexual contact networks, considering that the high number of sexual partners can increase the odds of risky practices for HIV infection and 
Statistics for analysis of network structures.

\begin{tabular}{|c|c|c|c|c|c|c|c|c|c|}
\hline Network & $N$ & M (edges) & $L$ * & $C * \star, * \star \star *$ & Global C & k\# & Mo \#\# & Normality test \#\#\# & $\begin{array}{c}\text { Distribution of } \\
\text { degrees } \S\end{array}$ \\
\hline $\begin{array}{l}\text { Recruiting chains } \\
\text { RDS (383.2) }\end{array}$ & 383 & 365 & 11.3 & 0.00 & - & 1.9 & 0.9 & - & - \\
\hline Network structure (383.2) & 383 & 370 & 7.4 & 0.01 & - & 1.9 & 0.8 & - & - \\
\hline $\begin{array}{l}\text { Basic network: } 60 \text {-day self- } \\
\text { reported network }\end{array}$ & 383 & $12 \S \S$ & - & - & 0.01 & 38 & - & Normality rejected & Any \\
\hline $\begin{array}{l}\text { Network structure } \S \S \\
(383.38, p=38 / 383=0.099)\end{array}$ & 383 & 7.342 & 2.2 & 0.05 & - & 38.3 & 0.1 & - & Normal \\
\hline $\begin{array}{l}\text { Networks of friends that would } \\
\text { invite to participate }\end{array}$ & 383 & $12 \S \S$ & - & - & 0.09 & 18 & - & Normality rejected & Any \\
\hline $\begin{array}{l}\text { Network structure } \S \S \\
(383.18, p=18 / 383=0.047)\end{array}$ & 383 & 3.424 & 2.8 & 0.02 & - & 17.9 & 0.2 & - & Normal \\
\hline Network of sexual partners & 383 & $12 \S \S$ & - & - & 1.2 & 5 & - & Normality rejected & Any \\
\hline $\begin{array}{l}\text { Network structure } \S \S \\
(383.5, p=5 / 383=0.047)\end{array}$ & 383 & 971 & 3.1 & 0.01 & - & 5.1 & 0.4 & - & Normal \\
\hline $\begin{array}{l}\text { Simulated small-world network } \\
+(\text { vertices }=383 \text { and Prob. }= \\
18 / 383=0.05)\end{array}$ & 383 & 4.596 & 2,5 & 0,07 & & 24 & 0,3 & - & - \\
\hline
\end{tabular}

* Minimum mean path;

** Clustering coefficient;

*** Latapy ${ }^{43}$ (calculated in Gephi); global C = Number of edges / (k(k-1));

\# Mean degree;

\#\# Modularity;

\#\# Shapiro-Wilk (a = 0.05);

$\S$ Test to verify scale-free distribution: log degree;

$\S \S$ Men who have sex with men that know each other in the network (mean self-reported);

$\S \S \S$ Simulations in Gephi;

+ Simulation in Pajek.

other STIs $35,36,38$. These findings were similar to those of other RDS studies 39,40,41 for all types of partners (steady, casual, and commercial). We highlight the positive correlation between the number of participants' links and study variables, indicating that older individuals with higher income and more education had more links (friends and sexual partners) in the networks.

In relation to the description of networks, friendship network proved to reflect the closest relationships, with more recent contact, unlike the overall network, which showed more distant relationships (acquaintances). The mean number of links dropped from 133 in the sexual partner network to $18 \mathrm{MSM}$ in the friendship network, similar to findings from other studies $34,35,36,37$. Recruiters had a mean of 12 MSM friends, reinforcing the tendency towards very close social relations among individuals in the friendship network. Further reinforcing this idea of close- ness, $50 \%$ of the participants knew up to five of the MSM in their recruiter's friendship network.

MSM clustering in this network was low, indicating that the MSM do not form a network comprised of groupings or clusters among their friends, that many of the recruiter's friends may not know each other despite belonging to the same social network. Analysis of the distribution of the participants' reported degree showed that only $10 \%$ of the MSM were linked to larger numbers of other MSM, that is, that they know more than 40 MSM each. Meanwhile, there were many more participants (90\%) with only two links (Figure 2a). Since this distribution did not appear as a power law, such information characterizes a "heavy tail" distribution of degrees, since only a few participants (five MSM) reported more than 150 links. According to descriptive analyses, these five MSM may be hustlers, thus explaining the high degree of linkage to other MSM. The 
Figure 2

Direct (2a) and scale-free relationship (2b) between self-reported degrees and their respective probabilities.

2a)
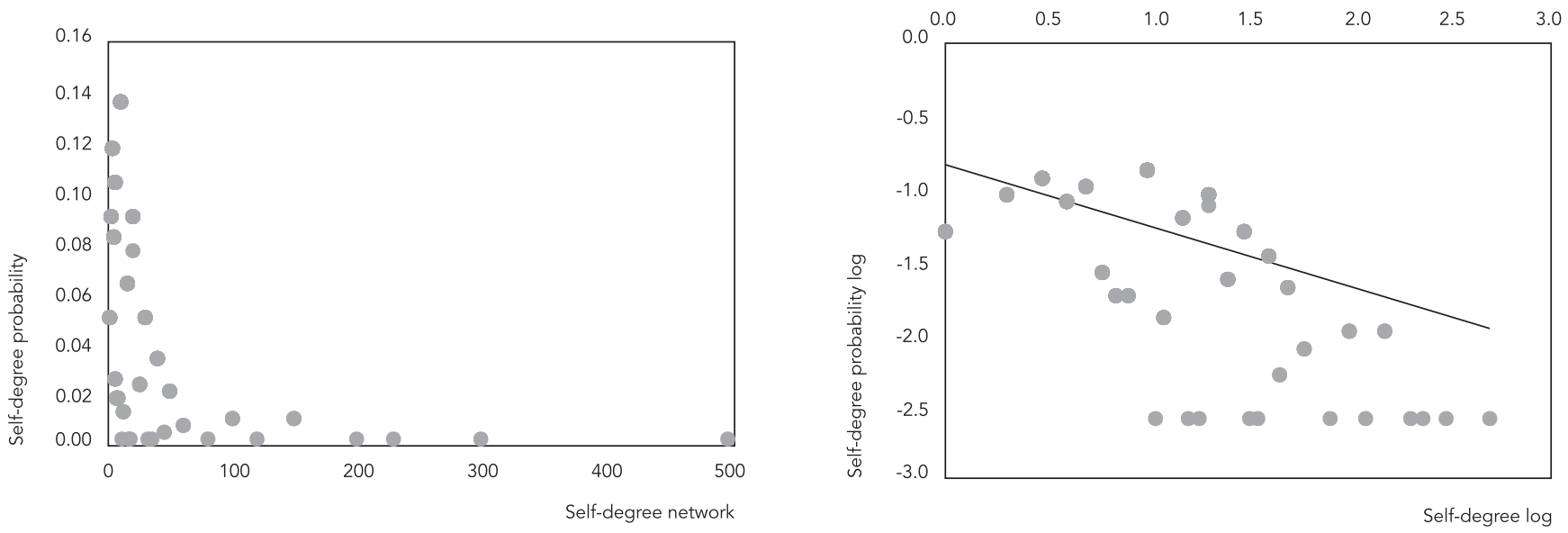

2b)
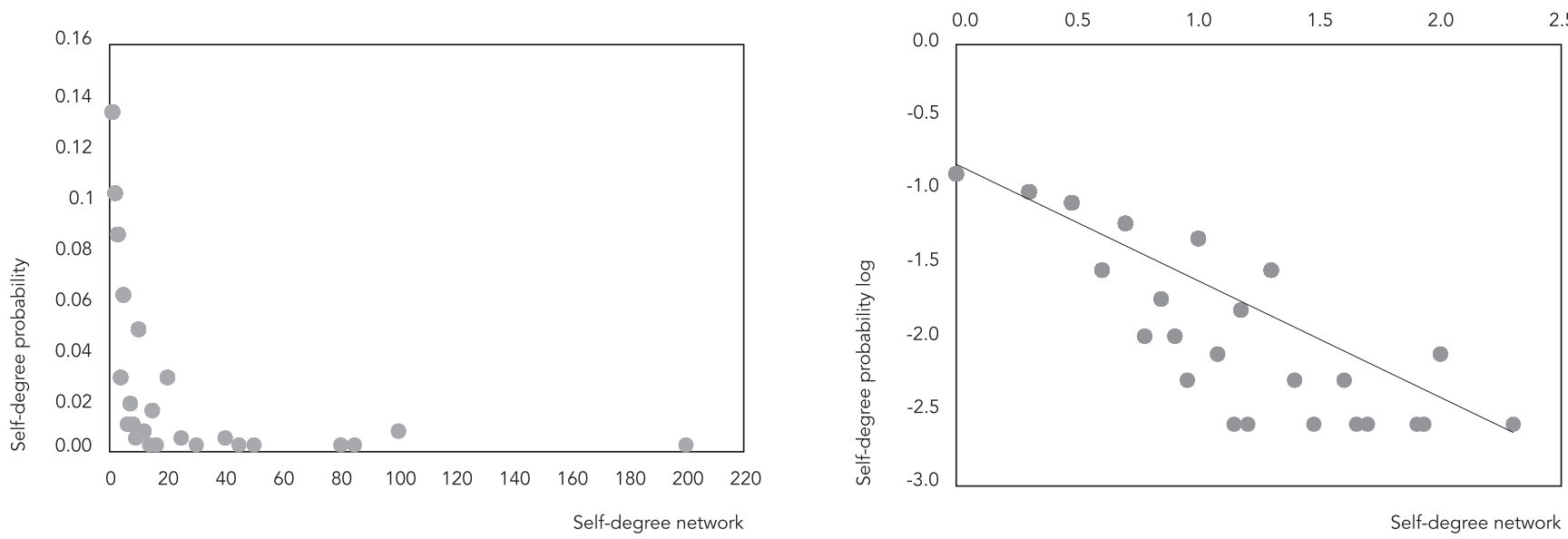

Note: self-degree is the number of links with other MSM in the networks, as reported by participants.

heavy tail distribution of degrees is similar to the distribution proposed by Resnick 33, describing "heavy tailed models", which are similar in some ways to power law, but with important differences. Thus, it was not possible to confirm that the friendship network was scale-free 17,18 , even with the presence of "nodes" or "hubs", that is, MSM with more links than the mean number for the network.

The sexual partner network showed similar characteristics to the friendship network, that is, with the characteristics of a small-world network, although with some MSM classified as hubs. Importantly, $25 \%$ of the participants reported having sex with more than four MSM in this network and $10 \%$ reported sex with more than 10 individuals in this structure. The global clustering coefficient was high $(C=1.0)$, much higher than for the simulated small-world network (0.07) (Table 2 ), that is, this network includes a large cluster of MSM, indicating that neighboring individuals in the network may be sexual partners. Thus, the MSM in this network are linked more as a function of their sexual partnerships, forming a 
compact, difficult-to-break network, except for the removal of a few MSM nodes or hubs. In the literature, other sexual networks have shown such characteristics of clustering and numerous links 36,42 . The distribution of the reported degrees follows the same pattern as in the friendship network, with a long tail and no confirmation of a power-law pattern.

What became obvious in these networks was the closeness of the MSM, as in a small-world network. In this type of structure, the mutual influence exerted by neighbors can be highly useful for interventions to prevent sexually transmitted infections. In addition, a small number of MSM showed more than the mean number of links in the network, similar to the hubs (nodes) in scalefree networks; these individuals can form the bridge between many individuals in the network due to their strong connectedness 15,17. Another indicator is the clustering coefficient, small in the friendship network, but large in the sexual partner network. Thus, assuming the hypothesis that this was a small-world network, greater clustering in the sexual partner network than in a random network with the same number of nodes and edges indicates that the spread of information/contagion in the network is important and can occur rapidly, since $C$ (1.0) was higher than expected in a random null model (0.07) (Table 2).

The results of this study provide unique information on the structure of the personal network of relationships for MSM, or friendship and sexual partner networks, i.e., information on the way MSM are linked in Salvador. These findings can be used for planning strategies so as to focus on "highly connected" individuals and those with more "prestige" in the network, with the expectation that they will encourage other MSM to avoid risky practices for HIV infection and other STIs 15,17 . One can also explore the potential for circulation of information within the target networks, in order to disseminate information on HIV/STIs prevention and care 15,16,17.

\section{Limitations}

The RDS methodology aims to reach individuals belonging to the participants' network of personal relationships, with some prerequisites 24 . However some of these requirements are difficult to meet, especially random selection of individuals from the personal network. Besides, it was not possible to calculate the minimum mean path in the networks, since there was no information on the number of links between MSM recruited by different recruiters. However, it was possible to perform a consistent exploratory analysis of the networks with the available data: information on the number of MSM in the overall network, which also included the participants' sexual partners. Information on the size of the network, number of sexual partners in the structure, and number of MSM that knew each other may not be precise, which can bias the estimates of the resulting coefficients. Dependency between the sampled units limits extrapolation of the findings on correlations between network size and number of sexual partners. Nevertheless, the study presented unique results on the structure of MSM networks in a large Brazilian city and can provide insight for future research to inform more precise measurements of friendship and sexual partner networks.

\section{Conclusion}

Difficulties in reaching the MSM population add further to issues of stigma and social discrimination 1,2 , beside other problems faced by the general population in large Brazilian cities. The MSM population also experiences increased social, individual, and program vulnerability in the context of HIV and other STIs 27. Given this adverse scenario, respondent driven sampling proved to be an efficient strategy to identify recruitment chains belonging to the network of personal relationships of MSM (social network).

The networks captured by the study present structures that can facilitate transmission and other STIs, but this can be minimized by factors not analyzed in this study such as strategies for partner choice according to HIV serological status, sex without anal penetration, and more consistent condom use 19,38,40.

The networks studied here can be explored to spread information on prevention of HIV and other STIs, given that the proximity and similarity among the MSM can encourage sharing positive behaviors and attitudes for prevention 16 .

Identification of the relationship between network size and number of sexual partners confirms the importance of the size of personal network in sexual behavior among MSM with more links 19,30,36,37,42.

In Brazil's third largest city 20 , within the overall problems and obstacles involved in living in a large urban area 22 , these results will hopefully be used to orient public policies to address contact with sexual diversity, especially facilitating health interventions that target the MSM population. 


\section{Resumen}

Redes sociales y de contacto sexual entre hombres que practican sexo con hombres (HSH) tienen un papel importante en la comprensión de la aparición de las enfermedades de transmisión sexual (ETS) y el VIH, debido a la posibilidad de circulación de los agentes infecciosos en estas estructuras. Los datos de Salvador, Bahía, Brasil, que se recabaron de la encuesta Comportamiento, Actitudes, Prácticas y Prevalencia de VIH y Sífilis entre Hombres que Practican Sexo con Hombres en 10 Ciudades Brasileñas, fueron recogidos en 2008/2009 en una muestra de 383 HSH, usando Respondent Driven Sampling. Se utilizó el análisis de redes sociales para investigar las redes de amigos y parejas sexuales. También se analizó la relación entre el número de conexiones (grado) y el número de parejas sexuales, y las características socio-demográficas. Las redes presentan estructuras que facilitan la transmisión del VIH. Sin embargo, se puede aprovechar para difundir información para prevención del VIH y las ETS, así como que la proximidad y la similitud de los HSH en estas redes pueden influir en el comportamiento y las actitudes positivas para la prevención de las mismas.

Homosexualidad Masculina; Conducta Sexual; VIH Red Social

\section{References}

1. Caiaffa WT, Ferreira FR, Ferreira DF, Oliveira CDL, Camargos VP, Projetti FA. Saúde urbana: "a cidade é uma estranha senhora, que hoje sorri e amanhã te devora". Ciênc Saúde Coletiva 2008; 13:1785-96.

2. World Health Organization. Our cities, our health, our future: acting on social determinants for health equity in urban settings. Report to the WHO Commission on Social Determinants of Health from the Knowledge Network on Urban Settings. Kobe: World Health Organization; 2008.

3. Parker RG. Abaixo do equador: culturas do desejo, homossexualidade masculina e comunidade gay no Brasil. Rio de Janeiro: Record; 2002.

4. Macrae E. Em defesa do gueto. In: Green JN, Trindade R, organizadores. Homossexualismo em São Paulo e outros escritos. São Paulo: Editora Unesp; 2005. p. 291-308.

5. Simões JA, França IL. Do "gueto" ao mercado. In: Green JN, Trindade R, organizadores. Homossexualismo em São Paulo e outros escritos. São Paulo: Editora Unesp; 2005. p. 309-36.

6. Guimarães CD. O homossexual visto por entendidos. Rio de Janeiro: Editora Garamond; 2004.

\section{Contributors}

S. M. S. Brignol contributed to the study project's conceptualization, data analysis and interpretation, and writing, critical revision, and approval of the final version for publication. I. Dourado, L. D. Amorim, J. G. V. Miranda, and L. R. F. S. Kerr contributed to the writing of the article, critical revision, and approval of the final version for publication.

\section{Acknowledgments}

The authors wish to thank the Department of HIV/AIDS and Viral Hepatitides of the Brazilian Ministry of Health and the Capes and CNPq research funding agencies, the coordinators of the project on Behavior, Attitudes, Practices, and Prevalence of HIV and Syphilis Among Men Who Have Sex with Men in 10 Brazilian Cities, Grupo Gay da Bahia, the study participants, NEPADI/ISC/UFBA, the science scholarship interns for their technical support, the team of interviewers and health professionals, and Rafaela Santos for her invaluable supervision.
7. Conselho Nacional de Combate à Discriminação, Ministério da Saúde. Brasil Sem Homofobia: programa de combate à violência e à discriminação contra GLTB e promoção da cidadania homossexual. http://bvsms.saude.gov.br/bvs/publicaco es/brasil_sem_homofobia.pdf (accessed on 20/ Oct/2014)

8. Ministério da Saúde. Política nacional de saúde integral de lésbicas, gays, bissexuais, travestis e transexuais. http://www.abglt.org.br/docs/Politi caNacional_SaudeIntegral_LGBT.pdf (accessed on 20/Oct/2014)

9. Grupo Gay da Bahia. Assassinato de homossexuais (LGBT) no Brasil: relatório 2013/2014. http:// homofobiamata.files.wordpress.com/2014/03/re latc3b3rio-homocidios-2013.pdf (accessed on 20/ Oct/2014)

10. Secretaria de Direitos Humanos da Presidência da República. Relatório sobre violência homofóbica no Brasil: ano de 2012. Brasília: Secretaria de Direitos Humanos da Presidência da República; 2012. 
11. Venturi G. Diversidade sexual e homofobia no Brasil. Intolerância e respeito às diferenças sexuais. http://www.fpabramo.org.br/node/5392 (accessed on 15/Apr/2011).

12. Perlongher N. O negócio do michê: a prostituição viril em São Paulo. São Paulo: Editora Fundação Perseu Abramo; 2008.

13. Mizruchi MS. Análise de redes sociais: avanços recentes e controvérsias atuais. Revista de Administração de Empresas 2006; 46:72-86.

14. Erdos P, Rényi A. On the evolution of random graphs. Publications of the Mathematical Institute of the Hungarian Academy of Sciences 1960; 5: $17-61$.

15. Christakis NA, Fowler JH. O poder das conexões: a importância do networking e como ele molda nossas vidas. Rio de Janeiro: Campus; 2010.

16. Watts DJ, Strogatz SH. Collective dynamics of 'small-world' networks. Nature 1998; 393:440-2.

17. Barabási AL, Albert R. Emergence of scaling in random networks. Science 1999; 286:509-12.

18. Barabási AL. Linked: a nova ciência dos networks. São Paulo: Leopardo Editora; 2009.

19. Beyrer C, Baral SD, van Griensven F, Goodreau SM, Chariyalertsak S, Wirtz AL, et al. Global epidemiology of HIV infection in men who have sex with men. Lancet 2012; 380:367-77.

20. Instituto Brasileiro de Geografia e Estatística. Indicadores sociais municipais. Uma análise dos resultados do universo do Censo Demográfico 2010. Rio de Janeiro: Instituto Brasileiro de Geografia e Estatística; 2011.

21. Programa das Nações Unidas para o Desenvolvimento. Atlas do desenvolvimento humano no Brasil 2013. Ranking IDHM Municípios 2013. http:// www.pnud.org.br/atlas/ranking/IDH-Globlal2013.aspx? (accessed on 20/Oct/2014).

22. Brevidelli MM, Freitas FCG. Estudo ecológico sobre o desenvolvimento da saúde no Brasil. Ciênc Saúde Coletiva 2012; 17:2471-80.

23. Kerr LR, Mota RS, Kendall C, Pinho AA, Mello MB, Guimarães MD, et al. HIV among MSM in a large middle-income country. AIDS 2012; 27:427-35.

24. Heckathorn DD. Respondent-driven sampling: a new approach to the study of hidden populations. Soc Probl 1997; 44:174-99.

25. Valente TW. Social networks and health: models, methods, and applications. New York: Oxford University Press; 2010.

26. Magnani R, Sabin K, Saidel T, Heckathorn D. Review of sampling hard-to-reach and hidden populations for HIV surveillance. AIDS 2005; 19 Suppl 2:S67-72.

27. Brignol SMS. Estudo epidemiológico da infecção por HIV entre homens que fazem sexo com homens no município de Salvador [PhD Dissertation]. Salvador: Instituto de Saúde Coletiva, Universidade Federal da Bahia; 2013.

28. Siegel S, Castellan Jr. NJ. Estatística não-paramétrica para ciências do comportamento. 2a Ed. Porto Alegre: Editora Artmed; 2006.

29. Freund RJ, Wilson WJ. Statistical methods. San Diego: Academic Press; 2003
30. Dorogovtsev SN, Mendes JFF. Evolution of networks with aging of sites. Phys Rev E Stat Phys Plasmas Fluids Relat Interdiscip Topics 2000; 62(2 Pt A):1842-5.

31. Newman MEJ. The structure and function of complex networks. SIAM Rev 2003; 45:167-256.

32. Clauset A, Shalizi CR, Newman ME. Power-law distributions in empirical data. SIAM Rev 2009; 51:661-703.

33. Resnick SI. Heavy tail modeling and teletraffic data: special invited paper. Ann Stat 1997; 25:180569.

34. Potterat JJ, Muth SQ, Rothenberg RB, ZimmermanRogers H, Green DL, Taylor JE, et al. Sexual network structure as an indicator of epidemic phase. Sex Transm Infect 2002; 78 Suppl 1:i152-8.

35. Potterat JJ, Phillips-Plummer L, Muth SQ, Rothenberg RB, Woodhouse DE, Maldonado-Long TS, et al. Risk network structure in the early epidemic phase of HIV transmission in Colorado Springs. Sex Transm Infect 2002; 78 Suppl 1:i159-63.

36. Liljeros F, Edling CR, Amaral LAN. Sexual networks: implications for the transmission of sexually transmitted infections. Microbes Infect 2003; 5:189-96.

37. Smith AMA, Grierson J, Wain D, Pitts M, Pattison P. Associations between the sexual behaviour of men who have sex with men and the structure and composition of their social networks. Sex Transm Infect 2004; 80:455-8.

38. Baggaley RF, White RG, Boily MC. HIV transmission risk through anal intercourse: systematic review, meta-analysis and implications for HIV prevention. Int J Epidemiol 2010; 39:1048-63.

39. Raymond HF, Kajubi P, Kamya MR, Rutherford GW, Mandel JS, McFarland W. Correlates of unprotected receptive anal intercourse among gay and bisexual men: Kampala, Uganda. AIDS Behav 2009; 13:67781 .

40. Mimiaga MJ, Goldhammer H, Belanoff C, Tetu AM, Mayer KH. Men who have sex with men: perceptions about sexual risk, HIV and sexually transmitted disease testing, and provider communication. Sex Transm Dis 2007; 34:113-9.

41. Carballo-Diéguez A, Balan I, Marone R, Pando MA, Dolezal C, Barreda V, et al. Use of respondent driven sampling (RDS) generates a very diverse sample of men who have sex with men (MSM) in Buenos Aires, Argentina. PLoS One 2011; 6:e27447.

42. Liljeros F, Edling CR, Amaral LAN, Stanley HE, Åberg Y. The web of human sexual contacts. Nature 2001; 411:907-8.

43. Latapy M. Main-memory triangle computations for very large (sparse (power-law)) graphs. Theor Comput Sci 2008; 407:458-73.

Submitted on 30/May/2014

Final version resubmitted on 29/Oct/2014

Approved on 14/Nov/2014 